\title{
Patients in Cardiac Rehabilitation Programme - Where We Were in 1999 and Where 10 Years Later
}

\author{
Inge Heim, Dubravka Kruhek Leontić, Vladimir Jonke, Mia Romčević, Mirjana Jembrek-Gostović and \\ Iva Henezi
}

Polyclinic for Cardiovascular Prevention and Rehabilitation, Zagreb, Croatia

\begin{abstract}
A B S T R A C T
The aim of this study was to find out and compare characteristics of cardiac patients who, after hospital treatment, participated in cardiac rehabilitation programmes at the Polyclinic for Cardiovascular Prevention and Rehabilitation in Zagreb during 1999 and 2009. The results show an increase in mean patients' age (men: 55.5 to $61.53 ; p=0.000$ and women: 58.95 to $62.66 ; p=0.01)$, an increase of the proportion of those \pm 65 years by $23 \%$ in both genders (men: $17 \%$ to 40\%; women: $27 \%$ to $50 \%$ ), an increase in the proportion of women (21.16\% to $28.22 \%$ ), a marked increase in the proportion of post - PCI patients with stenting (men: $15.58 \%$ to $61.92 \%$; women: $9.68 \%$ to $62.20 \%$ ), reduction of patients with BMI <25.00 kg/m (men: $47.19 \%$ to $13.93 \%$; women: $54.84 \%$ to $24.41 \%$ ) and a constantly high proportion of patients with hypercholesterolemia (above 85\%). It is obvious that systematic action is required to improve awareness of risk factors and desirable health behaviour.
\end{abstract}

Key words: cardiac rehabilitation, risk factors prevalence, secondary prevention

\section{Introduction}

Cardiac rehabilitation/secondary prevention is an integral part of a coronary patient's continuous care. Its aim is to help cardiac patients to recover quickly, to modify their risk factor profile and to adopt a healthy life style and so »to ensure the best physical, psychological and social conditions, so that patients with chronic or post acute cardiac disease may, by their own efforts, preserve or resume their proper place in society « 1 .

At any point in time this care has depended both on achievements in medical science and practice and on the characteristics of the coronary patients. During the last decade there has been significant progress in the field of cardiology in relation to diagnostic procedures, interventional cardiology and drug treatment of cardiac patients. Interventional cardiology and especially percutaneous transluminal coronary angioplasty (PTCA or PCI) has grown in Croatia since the first PTCA was performed in 1981. In 1999 there were 3 interventional cardiology units in Zagreb and one near Zagreb to which Zagreb residents were referred (Magdalena - Krapinske Toplice). In 2009 one more was added and others were enlarged so each year more PTCA procedures were performed.
At the same time international studies have shown that the new diagnostic and therapeutic procedures have changed the type of patients enrolled in cardiac rehabilitation markedly over the last decade. There are more elderly patients with multiple comorbidities, those with heart failure, with peripheral artery disease, more post-PCI patients with or without stenting, patients with heart valve replacements and with heart transplantation $^{2}$. This is the reason why we found it interesting to examine and compare the clinical profile of our patients who joined the cardiac rehabilitation/secondary prevention programme in 1999 and 2009.

\section{Material and Methods}

This study surveyed patients enrolled in the outpatient cardiac rehabilitation (CR) programme at the Polyclinic for Cardiovascular Prevention and Rehabilitation in Zagreb. In 1999293 (231 men and 62 women), and in 2009450 (323 men and 127 women) coronary patients were enrolled in cardiac rehabilitation. All were residents of the City of Zagreb and surrounding area. Criteria for enrolment: AMI (STEMI and NSTEMI), CABG 
surgery, PCI with or without stenting, stable angina pectoris, heart valve replacement, and heart transplantation. Detailed description of Outpatient Cardiac Rehabilitation Programme can be found elsewhere ${ }^{3,4}$.

On entering the outpatient cardiac rehabilitation programme patients were interviewed and examined. Information obtained included: personal and family history of coronary heart disease, information on risk factors (age, BMI, smoking, hypertension, hypercholesterolemia, diabetes mellitus, stress, heredity, etc). They underwent examinations such as: ECG, exercise test, blood tests, and during the rehabilitation other examinations such as: echocardiography, 24-hour ECG, etc. Cardiac rehabilitation programmes include monitored exercise training, education and counselling on nutrition and exercise, weight control, smoking cessation support, occupational counselling, psychosocial management and stress reduction $^{3,4}$.

In our study all the information on diagnoses and risk factors was taken from the discharge letter from cardiac rehabilitation.

We analysed data on diagnostic and therapeutic procedures, risk factor prevalence such as body mass index (BMI), hypertension, hypercholesterolemia, diabetes mellitus (NID, ID and impaired fasting glucose), smoking (smokers were those who smoked until AMI and those who stopped up to one year before AMI) and heredity (relative has had a heart attack before the age of 55 if they are male, 65 if they are female.). We compared data on coronary patients enrolled in cardiac rehabilitation programmes in 1999 and 2009 in order to find out if there were any changes in patients' clinical profile.

Descriptive statistics of percentages, means and standard deviation was used, as well as chi-square test. $p=0.05$ was considered significant.

\section{Results}

In 1999 , from the total of 293 patients $78.84 \%(\mathrm{~N}=231)$ were men, and $21.16 \%$ (62) were women. Mean age was 56.25 years; men $55.5 \pm 9.1$ (range $29-83$ years), and women $58.9 \pm 8.8$ year (range $33-73$ years). The difference in age between men and women was statistically significant $(\mathrm{p}=0.009)$.

In 2009 , there were 450 patients in cardiac rehabilitation. Mean age was 61.85 ; men $61.65 \pm 9.9$ years (range $37-84$ years) and women's $62.81 \pm 10.0$ years (range $32-82$ years), which was not a statistically significant difference $(\mathrm{p}=0.265)$.

The increase in age of cardiac patients between 1999 and 2009 , both in men and women was statistically significant, $p=0.000$ and $p=0.010$, respectively. The proportion of women increased from $21.16 \%$ in 1999 to $28.22 \%$ in 2009 . The proportion of male patients $\geq 65$ years in 1999 was $17 \%$ and female $27 \%$. In 2009 the proportion increased by $23 \%$ in both genders (Fig. 1).

The number of patients enrolled in the CR programme increased slowly from 1999 to 2009 (Fig. 2).

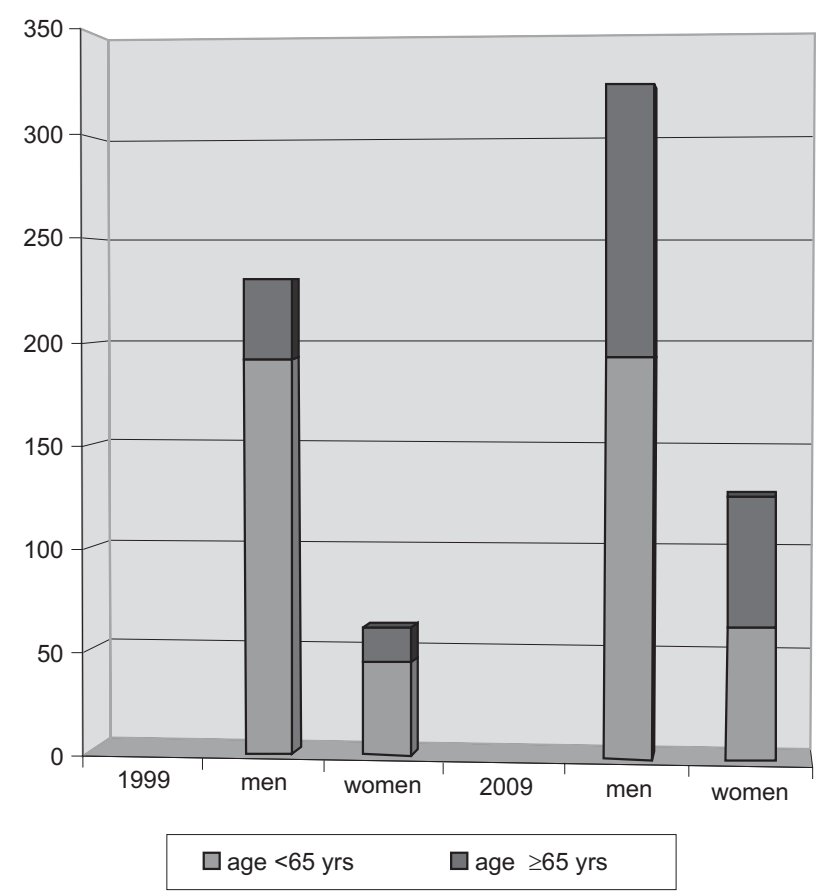

Fig. 1. The proportion of patients enrolled in cardiac rehabilitation in 1999 and 2009 by two age groups: <65 yrs and $\geq 65$ yrs.

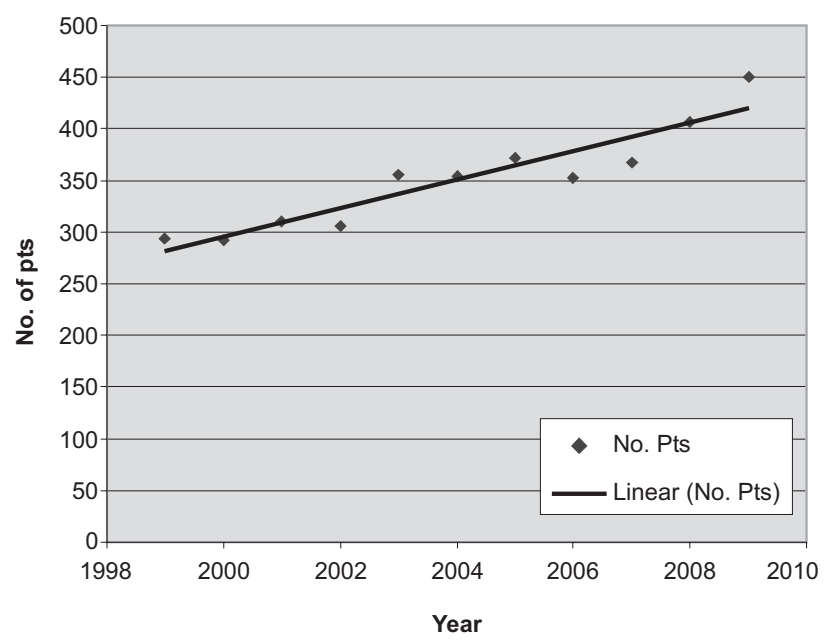

Fig. 2. The number of patients enrolled in outpatient cardiac rehabilitation in Polyclinic for Cardiovascular Prevention and Rehabilitation by year.

The proportion of men who suffered from myocardial infarction decreased from $78.8 \%$ to $72.7 \%$, and women increased from $58.1 \%$ to $63.8 \%, p=0.222$ and $p=0.333$, respectively. The proportion of patients who underwent PCI (PTCA) with stenting increased in men from $15.58 \%$ to $60.68 \%$, and in women from $9.68 \%$ to $60.77 \%, p=0.000$ and $p=0.000$, respectively. The percentage of those who underwent ACBG surgery did not change (Fig 3).

The proportion of those with normal BMI $<25.00$ $\mathrm{kg} / \mathrm{m}^{2}$ decreased in both men and women; in men from 


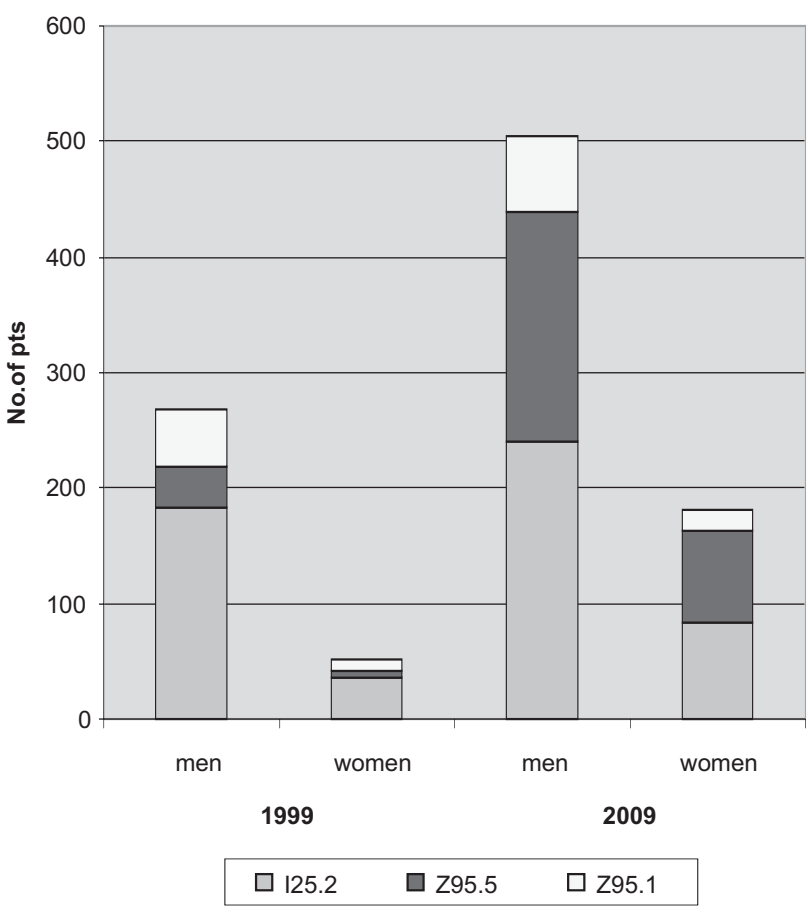

Fig. 3. The number of patients in 1999 and 2009 by diagnoses and gender. Legend: I25.2 = post MI; Z95.5 = PCI with stenting; $Z 95.1=A C B G$ surgery.

$47.19 \%$ to $13.93 \%(\mathrm{p}=0.000)$, and in women from $54.84 \%$ to $24.41 \%(\mathrm{p}=0.000)$. Consequently, the proportion of overweight and obese patients increased by $35.4 \%$ in men and $32.8 \%$ in women. There was no difference in weight between men and women in $2009(\mathrm{p}=0.985)$ (Table 1).

The proportion of patients with elevated blood pressure increased in men from $51.95 \%$ to $78.02 \%$ and in women from $74.19 \%$ to $83.46 \%(p=0.000$, and $p=0.132$, respectively). Hypercholesterolemia was present in more than $85 \%$ of patients in both years. The proportion of patients with diabetes (ID, NID and impaired fasting glucose) decreased in men by $10 \%$ and in women by $4.1 \%$. The proportion of smokers slightly decreased from $42.42 \%$ to $39.32 \%$ in men and in women from $32.26 \%$ to $27.56 \%$. At the same time the proportion of ex-smokers increased by $4 \%$ in men and by $6 \%$ in women (Table 1 ).

There was no change in family history of cardiovascular diseases (25\% in men and about $30 \%$ in women) between the two years (Table 1 ).

\section{Discussion}

Cardiac rehabilitation has been recognized as a part of the continuous care of cardiac patients ${ }^{5}$. But in spite of proven benefits ${ }^{6,7,8,9}$ only a small proportion of cardiac patients participate in CR all over the world (USA 10-30\%, Canada $24 \%$ and UK $14-23 \%)^{7,10}$. Only approx. $15 \%$ of post-MI patients joined outpatient CR in Zagreb ${ }^{4}$. Gains in long-term survival would be substantial if all eligible PCI patients received cardiac rehabilitation. Unfortunately, attitudes toward the need for cardiac rehabilitation differ from cardiologist to cardiologist and it is known from many studies that physician's recommendations strongly influence patient's decisions to participate in CR programmes ${ }^{11}$. Referral and enrolment in CR programmes in Croatia was low but there is a slowly rising trend of recognition that CR should be part of a patient's comprehensive care.

Many studies have shown that women are less likely to take part in a CR programmes ${ }^{11}$. There are many reasons why this is happening. Women are more often misdiagnosed than their male counterparts, they come more often to hospital after a delay, they more often have depression which interferes with their willingness to enrol in CR and they are less often referred to cardiac rehab programmes by their doctors ${ }^{11,12}$. Even when they are referred they are less likely to participate than men. Many

TABLE 1

RISK FACTORS IN PATIENTS ENROLLED IN OUTPATIENT REHABILITATION PROGRAMME IN ZAGREB IN 1999 AND 2009 BY GENDER

\begin{tabular}{|c|c|c|c|c|c|c|c|c|c|c|c|c|}
\hline & $\begin{array}{c}\text { Total } \\
\text { number }\end{array}$ & $\begin{array}{c}\mathrm{BMI} \\
<25.00 \\
\mathrm{~kg} / \mathrm{m}^{2}\end{array}$ & $\begin{array}{c}\mathrm{BMI} \\
\geq 25.00 \\
\mathrm{~kg} / \mathrm{m}^{2}\end{array}$ & $\begin{array}{l}\text { Hyper- } \\
\text { tension }\end{array}$ & $\begin{array}{l}\text { Hyper- } \\
\text { cholester- } \\
\text { olemia }\end{array}$ & $\begin{array}{c}\text { Diabetes } \\
\text { mellitus } \\
\text { ID }\end{array}$ & $\begin{array}{c}\text { Diabetes } \\
\text { mellitus } \\
\text { NID }\end{array}$ & $\begin{array}{c}\text { Impaired } \\
\text { fasting } \\
\text { glucose }\end{array}$ & $\begin{array}{c}\text { Diabetes } \\
\text { mellitus } \\
\text { ID+NID+GI }\end{array}$ & Smoker & Ex-smokers & Heredity \\
\hline 1999 & 293 & & & & & & & & & & & \\
\hline Men & 231 & 109 & 122 & 120 & 197 & 6 & 44 & 29 & 79 & 98 & 57 & 58 \\
\hline$\%$ & 78.84 & 47.19 & 52.81 & 51.95 & 85.28 & 2.60 & 19.05 & 12.55 & 34.20 & 42.42 & 24.68 & 25.11 \\
\hline Women & 62 & 34 & 28 & 46 & 55 & 1 & 7 & 11 & 19 & 20 & 10 & 18 \\
\hline$\%$ & 21.16 & 54.84 & 45.16 & 74.19 & 88.71 & 1.61 & 11.29 & 17.74 & 30.65 & 32.26 & 16.13 & 29.03 \\
\hline 2009 & 450 & & & & & & & & & & & \\
\hline Men & 323 & 45 & 285 & 252 & 282 & 14 & 39 & 26 & 79 & 127 & 91 & 82 \\
\hline$\%$ & 71.78 & 13.93 & 88.24 & 78.02 & 87.31 & 4.33 & 12.07 & 8.05 & 24.46 & 39.32 & 28.17 & 25.39 \\
\hline Women & 127 & 31 & 99 & 106 & 109 & 7 & 13 & 14 & 34 & 35 & 28 & 41 \\
\hline$\%$ & 28.22 & 24.41 & 77.95 & 83.46 & 85.83 & 5.51 & 10.24 & 11.02 & 26.77 & 27.56 & 22.05 & 32.28 \\
\hline
\end{tabular}


of the predictors are potentially modifiable with the help of better cooperation between health professionals and patients ${ }^{13}$. A study, performed in 2004, found that a little more than one-third of eligible women participate in CR, compared with two-thirds of men ${ }^{7}$.

If we consider that cardiovascular diseases are killer number one in women and that CR has a positive effect on their survival and improvement of their quality of life, then we have to find ways to persuade women to take part in CR programmes. In our study the proportion of women who participated in CR programmes increased in 2009 which means that there is a positive trend in referring women to CR programmes by their doctors.

It is well known that women get CHD later than men so it was not surprising to find out that in 1999 female coronary patients were older than male and the difference in age was statistically significant $(p=0.009)$, but by 2009 there was no difference in age between men and women. The age of the enrolled patients increased during the period of 10 years. The proportion of patients $\geq 65$ years also increased in both genders. Similar results can be seen in other studies ${ }^{11,14,15}$. One explanation is that survival is better because coronary angioplasty has prolonged patients' life. It can be performed several times, even after CABG surgery. Redo-coronary artery bypass surgery (RECABG) could also be more often done ${ }^{16}$.

The number of men with MI has decreased which means that in more cases CHD has been diagnosed before MI could develop and patients have been referred to coronary angioplasty earlier.

The number of coronary angioplasties performed increased markedly in both genders. This shows that more patients get to hospital in time for PCI to be done which saves their heart muscle and improves survival. There are also more interventional cardiology units where these procedures can be performed and more invasive cardiologists. European PCI guidelines were released in 2005. They are crucial for clinical practice as they give recommendations on treatment methods. So, coronary artery angioplasty with or without stenting has become the most common procedure for established coronary artery disease. At the same time the proportion of patients who underwent CABG surgery among our patients has not changed in the years observed. Surgery will always remain one kind of treatment especially for patients who are not candidates for PCI such as those with advanced multivessel disease and impaired left ventricular function.

The risk factor profile of our patients has changed between 1999 and 2009 but not necessarily for the better.
BMI, the number of patients with hypertension and the number of ex-smokers have all increased. Only $14 \%$ of men and $24 \%$ of women had normal BMI in 2009, which is very low, so we can say that BMI as a risk factor is seriously out of control. There was no difference in weight between men and women. Our prevention measures have obviously not been effective enough. Limitation: In 1999 BMI was not regularly measured and in those who were either obese or overweight cardiologists would note it as »obese«, which includes both overweight and obese. In 2009 BMI was measured regularly in all patients what enabled us to differentiate between overweight and obese patients. In order to be able to compare results we had to merge these two groups in both observed years.

The proportion of patients with hypertension increased in both genders (more in men). That could be due to the fact that in 2009 we have more obese patients and obesity is recognized as one of the most important risk factors for the development of hypertension ${ }^{17}$.

The proportion of patients with diabetes mellitus decreased although the proportion of obese patients increased and obesity is also associated with diabetes but the results are similar to other studies ${ }^{18}$.

Smoking as a risk factor was present in about $40 \%$ of male patients and $25 \%$ of female patients. There were only slight differences between 1999 and 2009. Similar results can be seen in other studies ${ }^{18}$. There is a small change for the better in 2009 when we have slightly more ex-smokers which means that all the anti - smoking campaigns that are regularly organised have some effect on our patients but still not enough.

\section{Conclusion}

Data on risk factors show that preventive measures are not effective enough and that there is still a lot to do to change the risk factor profile of our patients (improvement in lipid and lipoprotein profiles, body weight, blood glucose levels, blood pressure levels, and cessation of smoking). There is a great need for better health education of cardiac patients. Primordial and primary prevention are the first steps in the improvement of the cardiovascular health of the population. When the disease has already developed cardiac rehabilitation/secondary prevention is a vital part of the comprehensive care of cardiac patients ${ }^{19}$. More cardiologists should recognize CR as an integral part of cardiac care and should encourage referral to, enrolment in and completion of CR programmes.

\section{R E F E R E N C E S}

1. WORKING GROUP ON REHABILITATION OF THE EUROPEAN SOCIETY OF CARDIOLOGY, Eur Heart J, 13 (Suppl.) (1992) 1. — 2. AUDELIN M, SAVAGE P, ADES P, J Cardiopulm Rehabil Prev 28 (2008) 299. - 3. JEMBREK-GOSTOVIĆ M, JONKE V, GOSTOVIĆ M, HEIM I, Acta Med Croat, 63 (2009) 89. - 4. JONKE V, HEIM I, JEMBREK-GO-

STOVIĆ M, Tjelesna aktivnost i rehabilitacija u sekundarnoj prevenciji. In: REINER Z, (Eds): Prevencija ateroskleroze - Uloga tjelesne aktivnosti, (HAZU, Zagreb, 2009). - 5. WENGER, NK, J Am Coll Cardiol, 51 (2008) 1619. - 6. American Heart Association: Cardiac Rehabilitation Programs, Medical/Scientific Statement, Dallas: AHA, 1994. - 7. WITT 
BJ, JACOBSEN SJ, WESTON SA, KILLIAN JM, MEVERDENRA, ALLISON TG, REEDER GS, ROGER VL, Am J Coll Cardiol, 44 (2004) 988. - 8. MAHOVIĆ D, RAMQAJ T, CEROVEC D, GRBAVAC Ž, BABIĆ T, Coll Antropol, 28 (2004) 632. - 9. BALEN S, VUKELIĆ-DAMIJANI N, PERŠIĆ V, RUŽIĆ A, MILETIĆ B, SAMARDŽIJA M, DOMANOVIĆ D, MIRAT J, NAKI D, SOLDO I, VČEV A, Coll Antropol, 32 (2008) 285. 10. DALLAL H, EVANS PH, CAMPBELL JL, BMJ, 328 (2004) 693. - 11. ADES PA, WALDMANN ML, MCCANN WJ, WEAVER SO, Arch Intern Med, 152 (1992) 1033. — 12. JACKSON L, LECLERC J, ERSKINE Y, LINDEN W, Heart, 91 (2005) 10. — 13. GRAVELY-WITTE S, KAYANIYIL S, BRUAL J, SUSKIN N, STEWART DE, J Womens Health (Larchmt), 18
(2009) 209. - 14 COTTIN Y CAMBOU JP CASILLAS JM FERRIERES J, CANTET C, DANCHIN N, J Cardiopulm Rehabil, 24 (2004) 38. - 15. GOEL K, LENNON RJ, TILBURY RT, SQUIRES RW, THOMAS RJ, Circulation, 123 (2011) 2344. - 16. VAN ECK FM, NOYEZ L, VERHEUGT FW, BROUWER RM, Eur J Cardiothorac Surg, 21 (2002) 205. - 17. WOFFORD MR, HALL JE, Curr Pharm Des, 10 (2004) 3621. - 18. KHOT UN, KHOT MB, BAJZER CT, SAPP SK, OHMAN EH, BRENER SJ, ELLISON SG, LINCOFF AM, TOPOL EJ, JAMA, 290 (2003) 898. 19. TAYLOR RS, BROWN A, EBRAHIM S, JOLLIFFE L, NOORANI H, REES K, SKIDMORE B, STONE JA, THOMPSON DR, OLDRIDGE N, Am J Med, 116 (2004) 682

\section{Heim}

Polyclinic for Cardiovascular Prevention and Rehabilitation, Draškovićeva 13, 10000 Zagreb, Croatia e-mail: inge.heim@zg.t-com.hr

\section{SRČANI BOLESNICI U PROGRAMU AMBULANTNE REHABILITACIJE - GDJE SMO BILI 1999., A GDJE 10 GODINA KASNIJE}

\section{S A Ž E T A K}

Cilj ovoga rada bio je utvrditi i usporediti obilježja populacije srčanih bolesnika koji su sudjelovali u programu ambulantne rehabilitacije u Poliklinici za prevenciju kardiovaskularnih bolesti i rehabilitaciju 1999. i 2009. godine. Rezultati pokazuju porast prosječne dobi bolesnika (muškarci sa 55,5 na 61,53 godina; $\mathrm{p}=0,000$ i žene sa 58,95 na 62,66 godina; $\mathrm{p}=0,01$ ), veći udio starijih od 65 godina za $23 \%$ u oba spola (muškarci sa $17 \%$ na $40 \%$ i u žena sa $27 \%$ na $50 \%$ ), veći udio žena $(21,16 \%: 28,22 \%$ ), izrazit porast udjela bolesnika nakon PCI i ugradnje stenta (u muškaraca sa $15,58 \%$ na $61,92 \%$ i u žena sa 9,68\% na 62,20\%), znatno manje bolesnika s normalnim indeksom tjelesne mase (ITM $\left.<25.00 \mathrm{~kg} / \mathrm{m}^{2}\right)(\mathrm{u}$ muškaraca sa $47,19 \%$ na $13,93 \%$ i u žena sa $54,84 \%$ na $24,41 \%$ ), stabilno visoki udio bolesnika s hiperkolesterolemijom (oko 85\%). Iz dobivenih rezultata očito je da nam predstoji sustavni rad na razvoju svijesti o čimbenicima rizika i poželjnom zdravstvenom ponašanju. 